\title{
THE MARA ROSA GOLD DISTRICT, CENTRAL BRAZIL
}

\section{NELY PALERMO ${ }^{1}$, CLAUDIO GERHEIM PORTO ${ }^{2}$ AND CARLOS NOGUEIRA DA COSTA JR. ${ }^{3}$}

\begin{abstract}
In the Mara Rosa District, three different magmatic series have been identified and all of them host gold mineralization. The Mara Rosa Metavolcano-Sedimentary Sequence constitutes a poorly differentiated calc-alkaline magmatic series typical of arc settings. It is arranged into three belts, forming synclinal structures and was affected by high-grade amphibolite facies metamorphism. Early intrusive rocks of the Posse Unit show an alkaline affinity and host the epigenetic Posse Gold Deposit, which is associated with a late hydrothermal event, preferentially where earlier shear zones are present. Early hydrothermal alteration has produced an aluminous, sulphide rich greisen rock, which is barren of gold. Slices of an allochthonous and more magnesian sequence are associated with metachert and graphitic schists that host the syngenetic Au-Ag Zacarias mineralization and extensions. Gold-bearing quartz veins were emplaced before the second main isoclinal folding event. Supergene ore has played an important role in the mining activity of the Mara Rosa Region, since it represents the majority of the ore exploited. It is possible that yet undiscovered deposits lay hidden underneath the extensive lateritic cover.
\end{abstract}

Keywords: Gold, Volcanic Sequence, Mara Rosa, Brazil

INTRODUCTION The Mara Rosa Gold District is located in the northern portion of Goiás State within the Tocantins Tectonic Province (Almeida et al 1981). This orogenetic province results from the collision between the Amazon and São Francisco Cratons forming the Brasília and Paraguay-Araguaia Mobile Belts (Almeida et al 1981) These are separated by the Goiás Massif, that hosts Archean/ Paleoproterozoic granite-greenstone terrains and the Neoproterozoic Goiás Magmatic Arc, defined by Pimentel \& Fuck (1992). This Neoproterozoic terrain extends for approximately $300 \mathrm{~km}$ into the central portion of the Tocantins Province (Viana et al. 1995) and contains the Mara Rosa Gold District.

Regional mapping projects in the Mara Rosa Region (Machado et al. 1981, Ribeiro Filho 1981, Arantes et al. 1991) have associated the Mara Rosa Metavolcano-Sedimentary Sequence with gold mineralization (Lacerda, 1986) arranged into three belts (eastern, central and western) separated by tonalitic and granodioritic gnaisses (Fig. 1). Recent data on the nature and age of the rocks (Palermo1996 a,b, Viana et al. 1995, Junges 1998) have brought new impetus for the regional geological setting of the area and the understanding of gold mineralization. Three different magmatic series have been identified in the area and all of them host gold mineralization (Palermo 1996 a,b). The calc-alkaline series typical of arc settings is the most abundant in the belts and has been interpreted as part of the Neoproterozoic Goiás Magmatic Arc (Viana et al. 1995).

The Mara Rosa Region is heavily covered by lateritic regoliths, some 20 to $30-\mathrm{m}$ deep and product of intense tropical weathering, probably since the Tertiary. Laterization is mostly associated with the planation surfaces developed during the Velhas geomorphological cycle of the Lower Pleistocene. In the study area, remnants of these lateritic surfaces form an extensive plateau at the borders of which the Mara Rosa village is located (Fig.1). Elsewhere the landscape is dominated by a more undulating relief, product of the degradation of the lateritic surface under humid tropical conditions. Stone-line horizons, rich in quartz fragments but also containing remnants of lateritic material are commonly found as a product of this degradation. Bedrock exposure in the area is poor, making geological mapping a difficult task and exploration work a challenge.

This paper presents an overview of the Mara Rosa goldmineralization settings and its insertion into the geological evolution of the area.

EXPLORATION HISTORY Gold was first discovered in the area by the Portuguese settlers of the 18th century and was mined from alluvial and colluvial deposits. Since then, rudimentary mining activities exploiting centimetric to metric quartz veins have intermittently taken place, and it is estimated that about 30 to $40 \mathrm{~kg}$ of gold have been extracted in the last two decades (Palermo 1984). In 1980, Mineração Colorado (BHP-Utah Mining) started a systematic exploration campaign resulting in the discovery of the Posse Deposit in 1982, as a result of a soil gold panning anomaly. An underground drilling and excavation campaign, comprising some $12.000 \mathrm{~m}$ drillcore, a $100 \mathrm{~m}$ exploration shaft and $400 \mathrm{~m}$ length of galleries, were performed in order to define ore reserves. After a joint venture with WMC, the Posse open-pit reserves, calculated to a depth of $60 \mathrm{~m}$, constitute some $1.7 \mathrm{Mt}$ of ore at a grade of $2.24 \mathrm{~g} \mathrm{Au} / \mathrm{t}$ (Arantes et al. 1991). This includes oxide ore reserves of $0.4 \mathrm{Mt}$ at $2.0 \mathrm{~g} \mathrm{Au} / \mathrm{t}$ measured down to $5 \mathrm{~m}$ depth (Angeiras et al. 1987). Further exploration resulted in the discovery of the Zacarias Deposit, $11 \mathrm{~km}$ west of Posse, with reserves of $0.65 \mathrm{Mt}$ at $4.36 \mathrm{~g} \mathrm{Au} / \mathrm{t}$ and $48.06 \mathrm{~g} \mathrm{Ag} /$ $\mathrm{t}$ (Poll 1994). The Posse oxide ore was treated by cyanide heapleaching process and the primary Posse and Zacarias ores by the carbon in leach process. Following the Zacarias trend are the Cominas, Sorongo and Filó occurrences. These have been worked by small companies and it is estimated that reserves of about $8000 \mathrm{t}$ of ore at 2.8 g Au/t are present at Filó (Osborne 1992). Other deposits discovered in the region include Caranã with $1.13 \mathrm{t} \mathrm{Au}$ (Osborne 1992) and extensions of Posse deposit. About $60 \mathrm{~km}$ south of Posse Deposit, the Chapada $\mathrm{Cu}-\mathrm{Au}$ Deposit with $134 \mathrm{Mt}$ at $0.44 \% \mathrm{Cu}$ and $0.35 \mathrm{~g} \mathrm{Au} / \mathrm{t}$ (Richardson et al.1986) was discovered in the early 1970's.

GEOLOGICAL SETTING The area has been affected by a highgrade regional metamorphism and hydrothermal alteration. Primary rock textures have apparently been completely obliterated. Nonetheless, rock names with a genetic connotation are applied in regional mapping and especially in mine reports, usually lacking an integrated study of lithogeochemistry, petrography and field data. The undertaking of such a study, together with the identification of deformation, metamorphism and alteration events has led to a preliminary synthesis of the geological evolution of the Mara Rosa Region (Palermo 1996a), which is summarized below. Isotope geology revealed the age of some rock units as well as their geotectonic implications (Viana et al. 1995, Pimentel et al. 1997).

\section{THE MARA ROSA VOLCANO-SEDIMENTARY SEQUENCE}

The Mara Rosa Belts are mainly composed by amphibolites and hornblendites, leucocratic microcline gneiss, biotite plagioclase gneiss, kyanite-sillimanite-muscovite schist and/or quartzite, with rare metacherts with graphite layers and talc schists. Lithogeochemical studies based on the relative proportion of less mobile and incompatible elements in amphibolites have identified three groups of rocks representing three different, initial magmatic liquids (Fig.2a,b,c). Each group presents a distinct discriminant geochemical signature during magmatic evolution, as seen by the pattern of major and trace elements (Fig.3), interpreted as the result of three different magmatic series.

The more abundant magmatic series is represented by hornblendites, amphibolites and hornblende-biotite gneiss present in the three belts. They define a calc-alkaline series with minor tholeiitic terms typical of arc settings. Overlying this volcanic unit, is a sedimentary package represented mainly by plagioclase biotite gneiss interpreted as metagreywackes. Minor intercalations of quartzites, calc-silicate rocks and metapelites are also present. The above volcanosedimentary package constitutes the essence of the Mara Rosa Sequence. The tonalitic gneiss surrounding the Mara Rosa Belts has been dated by Viana et al (1995), giving a crystallization age of

1 Universidade do Estado do Rio de Janeiro, DGRG/FGEL.Rua São Francisco Xavier, 524 - Bloco A/224, Maracanã, Rio de Janeiro/RJ - CEP: 20559-900, e-mail: palermo@uerj.br

2 Universidade Federal do Rio de Janeiro, IG/Departamento de Geologia, Bloco G - Ilha do Fundão, Cidade Universitária, Rio de Janeiro/RJ - CEP: 21949900, e-mail: portoc@uol.com.br

3 Universidade de Brasília, Instituto de Geociências, Universidade de Brasília/DF, CEP: 70910-900, e-mail: carlong@unb.br 


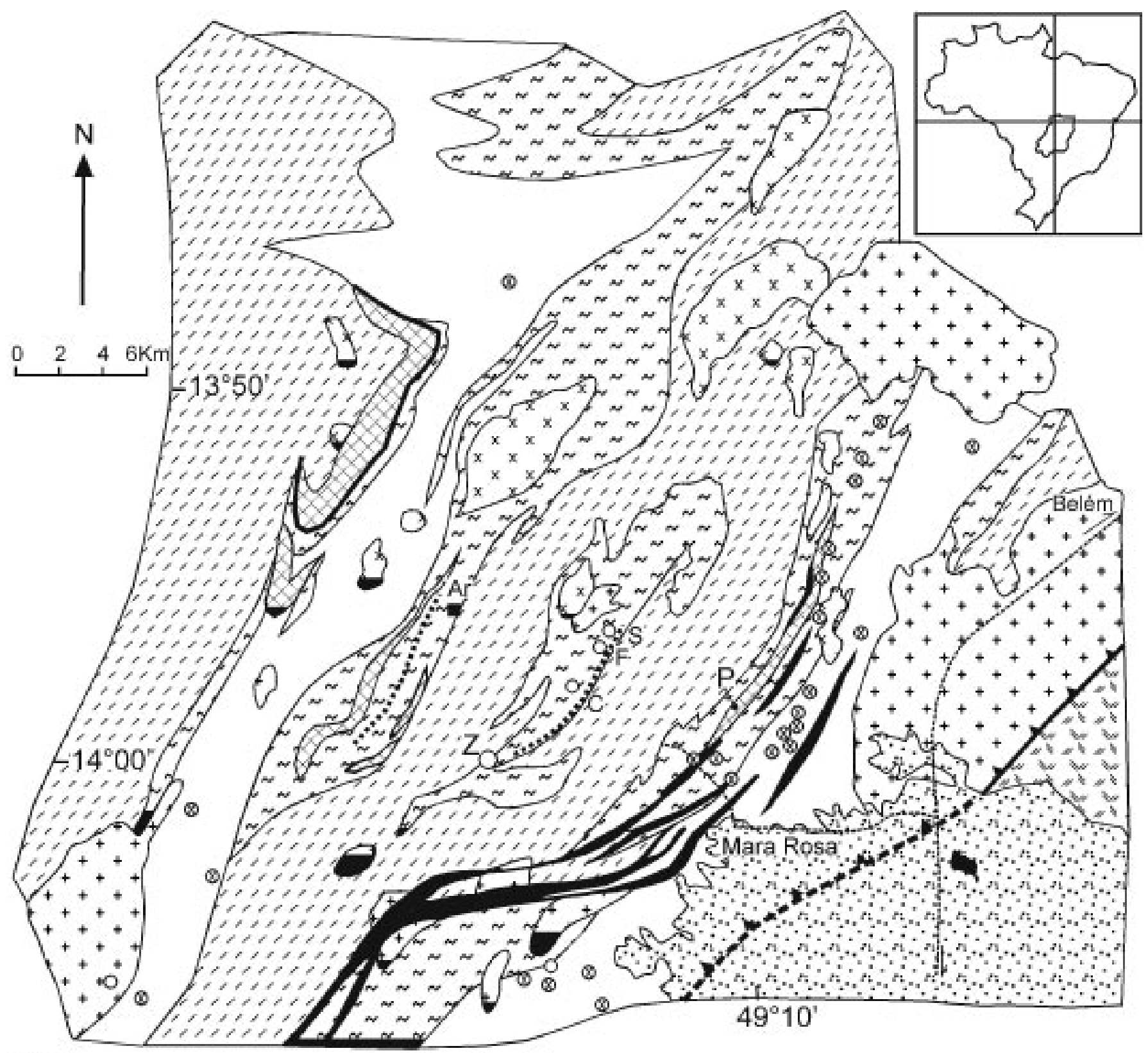

$\begin{array}{ll}\text { Lateritic cover } & \text { Mara Rosa Sequence } \\ \text { and diorites } & \begin{array}{l}\text { Posse } \\ \text { leucocratic } \\ \text { gneiss } \\ (862 \pm 8 \mathrm{Ma})\end{array} \\ \begin{array}{l}\text { Sillky-musc schists } \\ \text { (early alteration of } \\ \text { Posse Unit) }\end{array} & \end{array}$

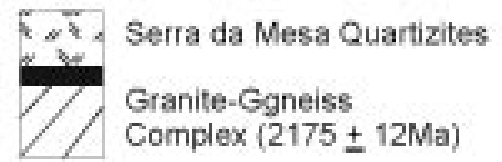

Complex $(2175 \pm 12 \mathrm{Ma})$

Figure 1-Simplified geological map of the Mara Rosa Region (modified from WMC Mineração Ltda 1991). Z: Zacarias Au-Ag Mine, P: Posse Au Mine, C: Cominas, F: Filo, S: Sorongo, X: gold-bearing quartz veins/alluvium/colluvium.

$856+13 /-7 \mathrm{Ma}(\mathrm{U} / \mathrm{Pb}$ in zircon), and has been interpreted by those authors as part of the Mara Rosa Sequence itself.

The allochthonous sequence A distinct geochemical group composed of pyroxene amphibolites, with relatively high $\mathrm{Mg}, \mathrm{Cr}$ and $\mathrm{Ni}$ and low variation of major and trace elements (Fig.3), occurs in close association with talc schists, actinolitites, graphitic levels and metachert in the central and western belts. These lithological assemblages are limited to bands (decametric width, up to $6 \mathrm{~km}$ long) parallel to the main foliation, intercalated in the amphibolites of calcalkaline affinity. They are preliminary considered as an allochthonous series into the Mara Rosa Sequence and may be interpreted as an oceanic fragment or volcanic rocks of komatiitic affinity. Gold mineralization has been identified in the metacherts of the central belt. 

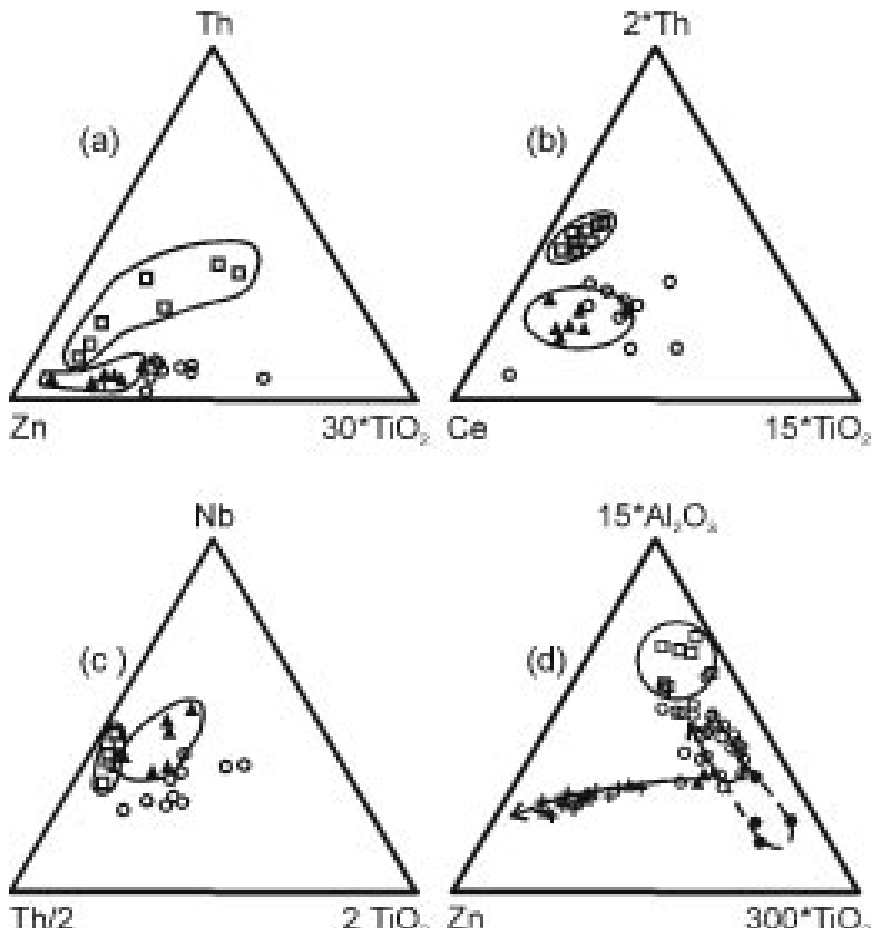

$\mathrm{Th} / 2$

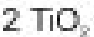

Zn

$300^{*} \mathrm{TiO}$

Figure 2-(a,b,c) Diagrams of incompatible elements for amphibolites ( $\mathrm{MgO}>6) ;\left(\right.$ d) Diagram $\mathrm{Al}_{2} \mathrm{O}_{3} * \mathrm{TiO}_{2} * \mathrm{Zr}$. Distinction of three magmatic series.

Early intrusive Posse Unit This unit has been identified mainly in the eastern belt where it hosts the Posse Gold Mine. It occurs as kilometric lenses intercalated in the amphibolites of the Mara Rosa calc-alkaline sequence and is represented by leucocratic microcline gneiss, generically named felsite. This gneiss is composed of microcline, plagioclase, quartz and minor biotite, sphene, apatite, zircon, epidote, allanite, garnet, muscovite, magnetite, ilmenite and pyrite. Minor decimetric lenses of amphibolite are found intercalated in the leucocratic gneiss in the Posse Mine. Their geochemical signature is similar to the sub alkaline granite series of Northern Goiás studied by Botelho (1992) (Fig. 2d). They show a characteristic $\mathrm{Zr}$ enrichment (up to $500 \mathrm{ppm}$ ) with constant alumina content, different from the Mara Rosa calc-alkaline sequence. Petrographic evidences for the intrusive nature of the leucocratic gneiss are the presence of antiperthite and local coarse grained textures. $\mathrm{U} / \mathrm{Pb}$ zircon dating gives a crystallization age of 862+/-8-Ma (Viana et al. 1995), and the model age is $1.0 \mathrm{Ga}$, which are similar to the $c a .856+13 /-7 \mathrm{Ma}$ tonalitic gneiss with the same model age. The interpretation of these data remains unresolved.

Late intrusives represented by diorites, gabbros and granites cut the entire rock package.

STRUCTURAL, METAMORPHISM AND HYDROTHERMAL EVENTS Structural field observations together with interpretation of existing geological maps have allowed an interpretation on the relative chronology of deformation. Major tectonic events are responsible for regional foliation (NE-subvertical NW-striking) and structural framework of the area into three synclines represented by the three Mara Rosa Belts (Fig.4). Thrust faults have laminated the overturned flanks of the large synclinal structures. The biotitization of amphibolites in the Posse and Zacarias Mines represents shear zones related to this event. Late deformations are represented by open folds and strike-slip faults with sinistral movement. Two peaks of metamorphism, both of the amphibolite facies, are identified, the earlier one giving rise to sillimanite-muscovite and hornblende-biotite assemblages and the later developing kyanite after sillimanite. Mineral isochrons indicate ages of $c a .750 \mathrm{Ma}$ and $610 \mathrm{Ma}$ for these metamorphic events (Junges 1998 and Morais et al. 1997).

At least two hydrothermal events have affected the Mara Rosa
Ni ppm
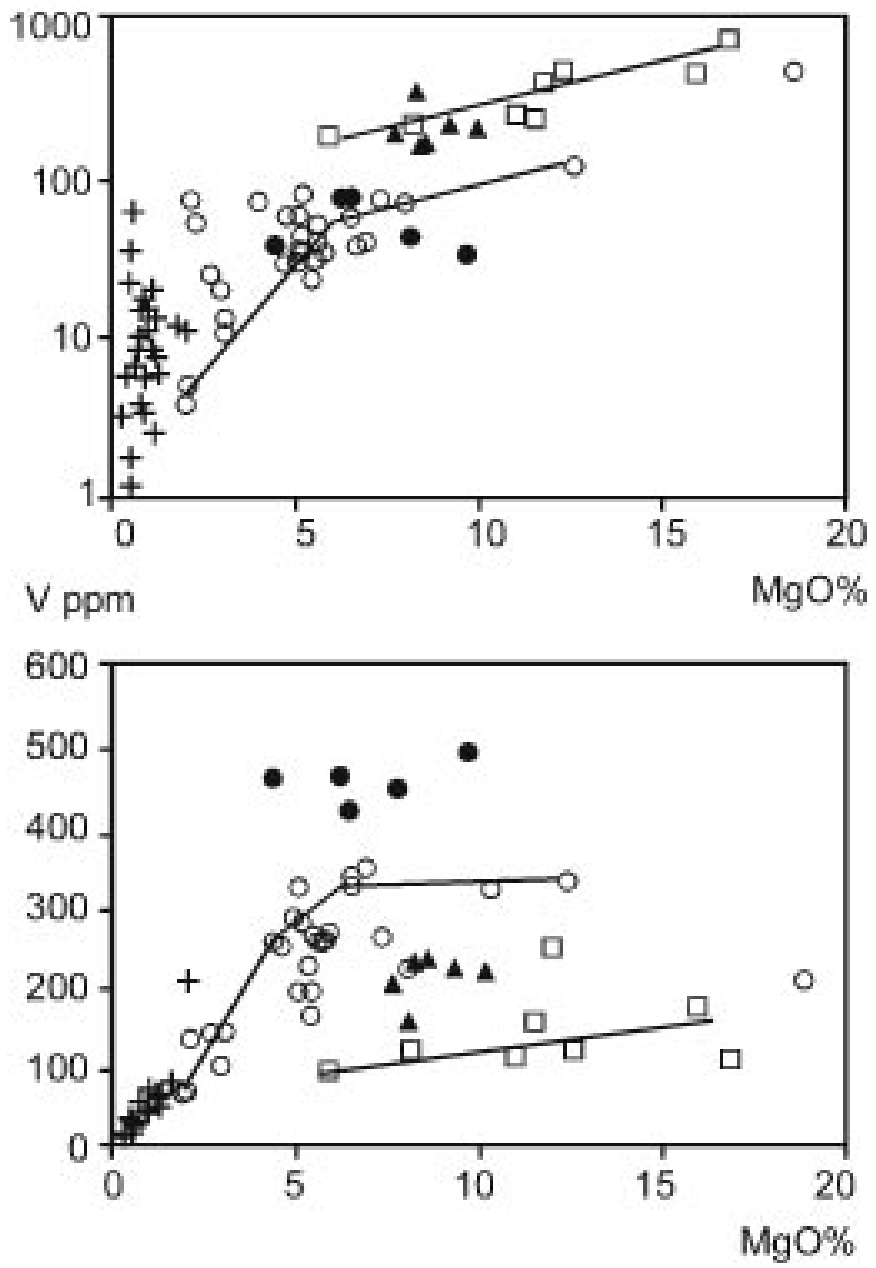

Figure 3-Diagrams $\mathrm{MgO}$ versus compatible elements for amphibolites, magmatic trend. Symbols as in Fig. 2.

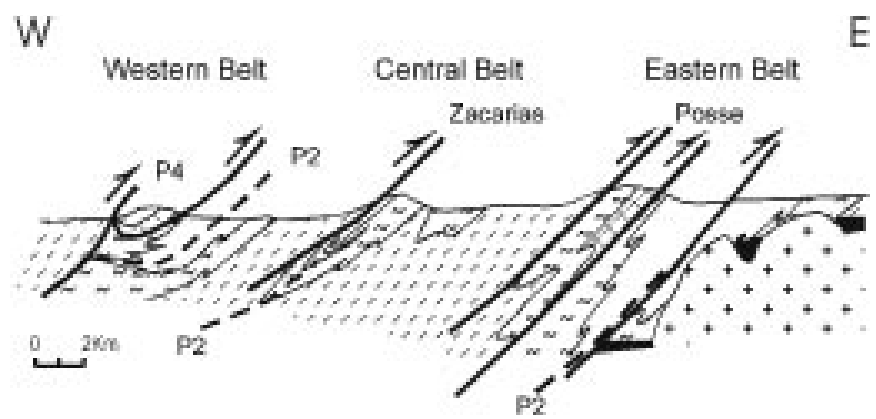

Figure 4-Profile through the Mara Rosa Belts, interpreted as synclinal structures of phase 2. Symbols as in Fig. 1.

Sequence including the Posse intrusive. The earlier one has produced quartz-muscovite-(kyanite)-sillimanite rocks derived from the intense and pre-metamorphic leaching of the Posse intrusive. The second event is post peak metamorphism and is characterized by the development of a mineral assemblage typical of greenschist facies conditions (epidote, actinolite, muscovite, quartz, albite and calcite), which are intense and diverse at Posse Mine.

GOLD MINERALIZATION Posse Gold Mine The mineralized zone extends for almost $1 \mathrm{~km}$ in a NNE direction with a thickness of up to $70 \mathrm{~m}$. It is hosted by the leucocratic Posse orthogneiss (Early Posse intrusive) near the contact with the Mara Rosa amphibolites, where the late hydrothermal event produced an 
intense alteration with the development of muscovite, epidote, quartz, albite, sericite and carbonate. Amphibolite and biotite sheared rocks from the Posse Unit are barren. Detailed analysis of primary gold under the SEM (Porto \& Hale 1996 and Palermo 1996) has revealed that about $90 \%$ of the gold occurs intimately intergrown with $\mathrm{Fe}(\mathrm{Au}$, $\mathrm{Ag}, \mathrm{Pb}$ ) tellurides as fine, disseminated grains up to $100 \mathrm{~mm}$ and the remainder as free isolated grains less than $10 \mathrm{~mm}$. This explains the relatively refractory nature of the ore to cyanide leaching (recoveries up to $65 \%$ ). In general, these mineralogical gold assemblages are also associated with Fe sulphides (pyrite, pyrrhotite, chalcopyrite). Gold fineness ranges from 938 to 1000 , with $\mathrm{Cu}(<0.58 \%)$ and $\mathrm{As}($ $<0.14 \%$ ) as trace elements.

Zacarias Au-Ag Mine It is situated about $15 \mathrm{~km}$ west of the Posse Mine. The mineralization is hosted by a barite quartzite, rich in a $\mathrm{Cr}$ Ba mica (oelacherite), intercalated in the amphibolites and ultramafics of the central belt. These are intensively altered to aluminous schists composed of a complex paragenesis made of biotite, phlogopite, sillimanite, kyanite, staurolite, cummingtonite, anthophyllite and talc. The orebodies are concordant with their hosting strata and form two major lenses, extending for about $700 \mathrm{~m}$ along strike (Poll 1994). Small-scale folds and boudins are observed throughout the orebodies, amphibolites and aluminous schists. Ore mineralogy studies by Marchetto (1990) and Page (1990) showed that gold grains are up to $40 \mu \mathrm{m}$ in diameter and of a high silver content. It occurs associated with galena, sphalerite, tetrahedrite, pyrite and minor chalcopyrite. It has also been observed as free grain close to quartz and barite. Gold recovery rates by carbon in pulp leaching are above 90\% (Poll 1994).

Other central belt occurrences The Zacarias ore horizon extends north for a few hundred meters along strike changing its composition to a sulphide-rich metachert with graphitic shale and manganiferous iron formation. These host Filó, Sorongo and Cominas orebodies, which occur in metachert lenses with minor intercalation of graphite bands, approximately one-meter thick with some galena and pyrite. Talc schist lenses and actinolitites probably belonging to the allochthonous series, are present in the footwall. Late, open folds are well observed in the pit. Filó and Sorongo were mined by rudimentary methods, resulting in extremely poor recovery rates $(<50 \%)$.

Gold bearing quartz veins in the eastern belt These constitute several small occurrences mostly hosted in the metagraywackes and amphibolites of the Mara Rosa volcanosedimentary sequence. Quartz veins vary from a few centimeters to a meter thick, and show massive to granular textures, sericite rich and foliated in places. They are concordant to subconcordant with regional foliation. Late isoclinal folds have affected the veins. Petrographic work shows quartz with deformation textures. Gold occurs as disseminated free grains or filling microfissures. Gold fineness ranges from 853 to 894. Pyrite and galena are present (Palermo 1983, 1984, Porto 1984) .

Morro do Caranã The Morro do Caranã occurrence is located 27 $\mathrm{km}$ northeast of the Posse Mine. It is composed by kyanite and pyrite rich micaschists enclosed by amphibolites and felsic rocks. Gold soil anomalies are associated with $\mathrm{Cu}, \mathrm{Te}, \mathrm{Se}$ and $\mathrm{Ba}$. The geological and geochemical characteristics suggest some similarity with the Posse environment, although Osborne (1992) has proposed a resemblance with the Zacarias geological setting.

Supergene gold Deep weathering and lateritization has produced gold concentrations in the regolith which constitute the bulk of the mineable ore in the area since colonial times. This ore has been mined as profitable small operations due to the soft nature of the host rocks and to the predominance of free gold. Deposits of this type includes alluvium/paleoalluvium, colluvium, including stone-line horizons, and residual, ferruginous, clay-rich materials such as latossoils, saprolites and mottled zones. Detailed studies at Posse (Porto 1991) show that the regolith is dominated by a 20-m thick saprolite zone where gold is mostly residually concentrated and constitutes most of the oxide ore. Morphological analysis of the gold grains under SEM shows that the close association of Au with tellurides in the primary ore is substituted in the regolith by an association of Au with limonite which is the result of the oxidation of the tellurides. This has produced an ore where $\mathrm{Au}$ is amenable to extraction by cyanide heap leaching with a recovery rate of $95 \%$. Gold enrichment by absolute accumulation occurs only within 1 to $2 \mathrm{~m}$ below the surface where a stone line horizon is present. Mass-balance calculations suggest that this enrichment may reach over $200 \%$. It results from chemical and mechanical processes, where gold is probably mobilized by organic compounds and migrates downwards by pedoturbation, related to the degradation of the lateritic surface. Gold is also laterally dispersed into the stone line and so are lateritic pisoliths highly enriched in $\mathrm{Te}(>50$

Table 1: Geological evolution of the Mara Rosa gold district

\begin{tabular}{|c|c|c|c|c|}
\hline Deformation & $\begin{array}{l}\text { Magmatism/ } \\
\text { Sedimentation }\end{array}$ & Metamorphism & $\begin{array}{l}\text { Hydrothermal } \\
\text { alteration }\end{array}$ & Mineralization \\
\hline $\begin{array}{l}\text { Late Deformations } \\
\text { (open folds, strike } \\
\text { slips aults) } \\
\text { Main Deformations } \\
\text { (foliation, regional } \\
\text { synclinals, shear) }\end{array}$ & $\begin{array}{l}\text { Late granites, } \\
\text { gabbros, diabase } \\
\\
\text { Early Posse Intrusive } \\
\text { Unit (U/Pb } 862 \text { Ma) } \\
\text { Allochthonous } \\
\text { Sequence } \\
\text { emplacement ?? } \\
\text { Mara Rosa Sequence } \\
\text { (volcanic-sed. } \\
\text { sequenc of arc } \\
\text { setting) }\end{array}$ & $\begin{array}{l}\text { Amphibolite facies } \\
\text { Metamorphism } \\
\text { (sillimanite/kyanite) } \\
(730 \mathrm{Ma} / 630 \mathrm{Ma})\end{array}$ & $\begin{array}{l}\text { Late hydrothermal } \\
\text { event } \\
\text { (musc+alb+carb+act+ } \\
\text { epid.) } \\
\text { Early hydrotermal } \\
\text { event (greisen type) }\end{array}$ & $\begin{array}{l}\text { Supergene gold } \\
\text { Au Posse Deposit } \\
\text { (tellurures, sulphide) } \\
\text { Au-bearing quartz } \\
\text { veins }\end{array}$ \\
\hline
\end{tabular}




\section{References}

ppm).

CONCLUSIONS According to the geological setting established for the area, an evolutionary geological framework for gold mineralization is proposed. This is schematically displayed in table 1 which uses the regional deformation events as a relative chronological scale.

There are at least four episodes of ore generation in the study area. The oldest one is represented by the Zacarias Au-Ag Mine and its extensions. These are hosted by chemical sediments (barite quartzite and graphite rich metachert) associated to the allochthonous sequence and are probably of a syngenetic origin (Poll 1994). The second episode of gold mineralization is associated with quartz veins in weathered metagreywackes and amphibolites of the Mara Rosa Sequence. These veins were emplaced at least prior to the second isoclinal deformational phase. The Posse Gold Mine represents the third event of mineralization. It is related to late hydrothermal mineral assemblages formed in previously sheared rocks of the Posse Intrusive Unit and is considered to be of a epigenetic origin. Gold here is of a high fineness, which contrasts to the syngenetic Ag rich ore at Zacarias. Supergene ore represents the last event and has played an important role at the mining activity of the Mara Rosa Region since it represents the majority of the ore exploited. It is possible that undiscovered deposits lay hidden underneath the extensive lateritic cover.

Almeida F.F.M.de, Hasui Y., Neves B.B.de, Fuck R.A. 1981. Brazilian structural provinces: an introduction. Earth Science Review, 17:1-29.

Angeiras A.G., Moutinho de Costa L.A., Camargo dos Santos R. 1988. Depósito de ouro de Mara Rosa, Goiás. In: C. Schobbenhaus \& C.E.S. Coelho (eds), Principais Depósitos Minerais do Brasil, V.III, Brasília, DNPM, p.523-534

Arantes D., Osborne G.A., Buck P., Porto C.G. 1991. The Mara Rosa volcano-sedimetary sequence and associated gold mineralization. In: BRAZIL GOLD'91. Balkema, Rotherdam, 1991. Proceedings, Belo Horizonte, 221-229.

Botelho, N.F. 1992. Les ensenbles granitique subalcalins à peralumineux mineralisás en Sn et In de las sous-province de Paraná, Etat de Goiás, Brésil. Thèse de l'Úniversité Paris VI, France, $344 \mathrm{p}$.

Junges S. 1998 Caracterização Geoquímica e Isotópica da Faixa Oeste da Sequência Vulcanosedimentar de Mara Rosa, Instituto de Geociências, Universidade de Brasília, M.Sc. Thesis.

Lacerda H. 1986. As mineralizações auríferas da região de Mara Rosa (GO). Rev. Bras. Geoc. 16(3):274-284

Marchetto C.M.L. 1990. Petrographic study of samples frm the Zacarias area. WMC Mineração Ltda., unpublished report.

Machado E.C., Souza S.J., Silva M.A, Berbert C.O. 1981. Projeto Porangatu, Etapa II, final report, DNPM/CPRM, Goiania, Brazil

Morais R., Pimentel M.M., Jungs S. 1997. Condições de P-T e idade do metamorfismo da sequência vulcano-sedimentar de Mara Rosa, Goiás. In: South-American Symposium on Isotope Geology, 1, Campos do Jordão, Brazil.

Osborne G.A. 1992. Monthly exploration report. WMC internal report. Unpublished.

Page M.L. 1990. Technical report, Zacarias and Posse metallurgy. WMC internal technical report. Unpublished.

Palermo N. 1996 a. Le gisement aurifère précambrien de Posee (Goiás, Brésil) dans son cadre géologique. Thèse da ENS das Mines de Paris, $175 \mathrm{p}$.

Palermo N. 1996 b . Identificação de tres séries magmáticas na região de Mara Rosa, Goiás. In: Cong. Bras. Geol., 39, Salvador, Anais, 5:219-222.

Palermo N. 1984. Localização e amostragem de veios de quartzo no trend dos garimpos do Badé e tres Barras, Mara Rosa. Relatório interno, Mineração Colorado, Ltda. Rio de Janeiro.

Palermo N. 1983. Relatório dos garimpos de Mara Rosa. Relatório Interno, Mineração Colorado, Ltda. Rio de Janeiro.

Pimentel M.M., Oliveira C.G., Valle F.S.B. 1998. New Sm-Nd isotopic data for the Mara Rosa-Porangatu region, northern Goiás: implications for the limit of the neoproterozoic Mara Rosa arc. In: International Conference on Basement Tectonics, Ouro Preto, Brazil, Abstracts, 53-54.

Pimentel M.M. \& Fuck R.A.1992. Neoproterozoic Crustal Accretion in Central Brazil. Geology, 20:375-379.

Pimentel M.M., Whitehouse M.J., Viana M.G., Fuck R.A., Machado N. 1997. The Mara Rosa arc in the Tocantins Province: further evidence for Neoproterozoic crustal accretion in Central Brazil Precambrian Research 81:299-310.

Poll J.S. 1994. The geology of the Zacarias gold-silver-barite deposit, Goiás State, Brazil, Colorado School of Mines, MSc. Thesis, 124p.

Porto C.G. 1983. Projeto Mara Rosa fase I. Relatório Interno, Mineração Colorado Ltda. Rio de Janeiro.

Porto C.G. 1991. Lateritic weathering and gold redistribution in the Posse deposit, Central Brazil, Imperial College, University of London, PhD Thesis 345p.

Porto C.G. \& Hale M. 1996. Mineralogy, morphology and chemistry of gold in the stone line lateritic profile of the Posse deposit, Central Brazil. J. Geoch. Explor, 57:115-125.

Ribeiro Filho W. 1981. Reavaliação da geologia de Pilar-Mara Rosa. In: SBG, Simpósio da geologia do Centro-Oeste, 1, Goiania, Brazil, 281-299.

Richardson J.V., Jones J.P., Essene E.J., Kesler S.E. 1986. Origin and geochemistry of the Chapada $\mathrm{Cu}-\mathrm{Au}$ deposit, Goiás, Brazil: a metamorphosed wall-rock porphyry Copper deposit. Econ. Geol., 81:1884-1898.

Viana M.G., Pimentel M.M., Whitehouse M.J., Fuck R.F., Machado N. 1995. O arco magmático de Mara Rosa, Goiás: geoquímica e geocronologia e suas implicações regionais. Rev. Bras. Geoc. 25(2):111-123. 